\title{
Radio as a Transmitter of Culture-specific Knowledge in the Age of Edutainment
}

\begin{abstract}
Considering that the acquisition of culture-specific knowledge through listening to the radio is possible in the era of globalization and media convergence, this article analyses the topic of basic mass media functions and shows them through the prism of their hybridization. In consequence, it demonstrates the cultural role of modern radio but in the context of the edutainment approach. As a key example to discuss this issue serves the long-term cooperation between Fun Kids radio and the Polish Cultural Institute in London that has resulted in three radio series: “Where in the World? Poland!”, “Learn Polish!”, and “Robot’s Polish Power Pack". Referring to them, the text explores how educational and entertaining functions of radio programmes may be combined to deliver content that inspires and engages young listeners as well as nurtures cultural ties between the UK and Poland, which is especially important nowadays, in the face of Brexit. The methodological framework of this study is mainly a subjective literature review. However, the theoretical analysis is extended with a case study that is based on the radio report provided by the Fun Kids radio manager, observations of contemporary mediasphere as well as a personal examination of episodes of selected radio broadcasts.
\end{abstract}

\section{Keywords:}

radio, edutainment, hybridization of media functions, culture-specific knowledge, broadcasts for children

1 Department of Journalism and Social Communication, University of Łódź, Poland. E-MAIL: albinskakarolina@yahoo.com ORCID: 0000-0001-7372-4526 


\section{THE CULTURAL ROLE OF RADIO}

"Culture is communication and communication is culture", claimed anthropologist Edward T. Hall (1959) in his noted book The Silent Language. The same thesis was also repeated by many other scholars who noticed a tight connection between these two notions (Dumitrescu, 2013; Golka, 2008). Certainly, this statement is a mental shortcut, yet it shows succinctly that "communication and culture reciprocally influence each other. The culture in which individuals are socialised influences the way they communicate and the way individuals communicate can change the culture" (Giri, 2006, p. 124) as "culture and communication have a symbolic relationship. Culture determines the code, context and meaning of communication; and communication is the life wire of any culture; without communication, no culture can survive” (Moemeka, 1989, p. 4).

Above all, it seems true when the environment of human existence is taken into consideration since mass media are a quintessence of human communication. They constitute the core of it. This issue is elucidated by Goban-Klas (2005), who believes that the 20th century was already the age of media and communication. In fact, the communication landscape of the present era also deserves to be called "mediasphere" because mass media impinge on every aspect of everyday existence of individuals, groups and societies. Therefore, some scholars write about "Media society", while others, who refer to the nature-culture dichotomy and equate culture with civilization, speak of "Media civilization" or "multimedia civilization". In so doing, they put the stress on the fact that mass media are "the synonym of postmodernism, its main indicator and the perpetrator of the changes that are taking place in front of our eyes” (Drzewiecki, 2010, p. 34).

Indeed, mass media determine the character of culture by constituting the “cultural order" of the 21st century. On the other hand, culture changes man's "anthropological equipment from potentiality into reality” (Hopfinger, 1985, p. 57) and, what follows, decides which media are in the repertoire of people's means of communication because they are "extensions" of human senses - to use McLuhan's (1964) terminology.

With this in mind, it is obvious that Marconi's invention was the first electronic device that inscribed itself deeply into "media culture”. A glance back in time does reveal that even in its simplest form radio has fulfilled the cultural function since it has served the communication purpose. No wonder then that this audio medium is sometimes defined as "communication through the use of radio waves" (Understanding Media and Culture..., 2017, p. 256). What is more, from the very beginning it worked - and still works - in micro and macro scale alike to unite listeners 
and reach the most far-flung corners of the planet. There is no denying that due to radio broadcasting, communication has become personal but widely received. This medium, as a result, plays crucial role in the process of social integration as well. For this reason, McLuhan (1964), using a vivid metaphor, compared this type of transmission to a tribal drum, noticing that radio has "power to turn the psyche and society into a single echo chamber” (p. 331).

To put it bluntly, the cultural function of radio - in its classical and digital form - stems not only from the fact that this medium plays a crucial role in the process of social communication but also from its integrational potential and ability to constitute identities of both individuals and societies. Hajduk-Nijakowska (2012) follows this way of thinking and postulates that: "the condition for the functioning of culture is its message. Thus, communication, understood as a semiotic interaction, as a continuing cultural process, not only guarantees the continuity and sustainability of culture, but also affords the society that is the subject of this culture the sense of identity and lasting” (p. 149-150). Wielopolska-Szymura (2014) also supports this view by saying that: "traditional radio plays a significant role in expanding knowledge of national culture and society, and it supports cultural creativity and civic participation in the public sphere. Everywhere where it provides some cultural output, it demonstrates its most important and specific characteristics and thereby helps to sustain the cultural identities of communities both large and small” (p. 115).

It must be stressed, however, that the cultural role of all mass media - and radio in particular - should be perceived through the prism of plurality since the cultural function is not only limited to two aspects that have been already discussed. The five-fold classification proposed by Gajda (2000) may serve as a useful illustration of this problem. According to it, "culture-creative functions" are as follows: the function of popularizing various messages, the interpersonal function, the model-making function, the stimulating function, and the ludic function. What is remarkable about these primary “culture-making” functions of radio is that they are always accompanied by additional ones. Sarnoff, the American radio pioneer, enumerated them, saying that "broadcasting represents a job of entertaining, informing and educating” (Lord Pattern..., 2011, p. 1). Once, these three subfunctions were clearly separated. In Poland, this division was valid till the end of the nineties of the past century. In other countries, the demarcation lines between informative, educational and entertaining broadcasts started to disappear much earlier.

Nowadays, in the age of globalization, the hybridization process is very advanced. Unfortunately, it is impossible to discuss this topic thoroughly in this 
text, owing to editorial restrictions on its length. Here it is worth saying, however, that the multidimensional hybridization process plays such an important role that contemporary radio programmes more and more often take the form of "cute and threatening mixtures" because "media messages have become an area where mixed, blurred, liquid forms and conventions are acceptable, and all homogeneity is rather seen as a disadvantage than an advantage” (Bauer, 2009, p. 86). This trend is analysed by Fras (2012), who is convinced that all media units (utterances), to a greater or a lesser degree, are subject to the phenomenon of hybridization. In the same vein, she defines "hybrid utterance" in the mass media context as "the utterance that combines two or more [media] genres of completely different definitional features (determinants), especially distinct functions; also merging genres that belong to different systems of signs" (Fras, 2012, p. 22). For some of them, the term "edutainment" has been coined that reflects the specific "marriage” of media functions. To support this view, Iwanicka (2010) insists that: "Edutainment [...] is an activity that combines education with entertainment and uses mass media as the primary channel of communication with a recipient” (p. 307). The media factor, therefore, makes this concept inseparable from the notions of culture and civilization (Piechota, 2010a).

\section{THE EDUTAINMENT APPROACH AND RADIO PROGRAMMES}

At first glance, the idea of edutainment seems to be unambiguous. Drawing from what the original nomenclature means, it is rather obvious that the neologism "edutainment" has been coined from the words "education" and "entertainment" to imply the cross-fertilization of two strictly defined media functions. On closer examination, however, this issue is not as simple as that, for at least a few reasons. Firstly, more and more often media genres - and radio genres as well - combine within their structures all three functions. They are created to educate, entertain and inform their audience at the same time. In line with this, it is postulated that a more adequate term should be invented to describe these functional blends - probably "info-edutainment". Besides this, even if most media experts agree that media functions, as a rule, work in tandems, it is not at all clear which functional element in edutainment combination is more important, not least because it is impossible to specify or measure the exact proportion of the ingredients in this functional mixture. In consequence, both labels - "edutainment" and "infotainment" - are sometimes used interchangeably, which makes this phenomenon even more vague. From the standpoint of Singhal and Rogers (1999), both features of this cluster are equally 
vital, or at least they should be, because the key idea of edutainment approach is to combine both functions in media broadcasts in order "to obtain certain advantage from each" of them (p. 9). Most commentators, however, say that the hierarchy of media functions is, once and for all, established. In general, education is valued higher, even if entertainment is "overideology" or "macrointention". In these circumstances, the primary aim of edutainment programmes is to support education with entertainment since edutainment is in fact a new form of learning. For this reason, it is also called “education-entertainment” (Singhal \& Rogers, 1999, p. 10) or "Education by Entertaining” (Piechota, 2010b, p. 308). Simply speaking, entertainment is just a useful method to hide the fact that learning is happening at all. It is nothing more than an attractive “wrapping” for educational media content. Yet, radio broadcasts need not to be funny to be classified as edutainment content. Instead, they must be interesting for their audience or encourage them to play an active role in a learning process. In this vein, Bełkot (2007) identifies two types of edutainment - "edurozrywka” [edu-fun] and "eduzabawa” [edu-play] - to differentiate a passive attitude of a subject who learns while filling its free time and an active attitude of a subject who learns while taking part in a play activity. Either way, the idea of using entertainment for serious educational purposes has gained enormously in popularity in the age of convergence, when listeners have become "producers" and radio has gone far beyond typical AM and FM transmission.

Taking this into consideration, Piechota (2009) looks at the edutainment phenomenon from somewhat different angle. According to her, it can be thought of as "any form of activity undertaken by individuals or organizations for educational purposes that uses entertainment forms to show specific content to the audience" (pp. 206-207). This definition brings to the fore another crucial aspect of the synergy of education and entertainment, namely the thematic scope of the broadcasts that "grew out of a recognition of, and as a counter to, at least two undesirable trends in contemporary mass media programming: entertainment-degradation programmes, and boredom-education programmes” (Singhal \& Rogers, 1999, p. 11). Therefore, media broadcasts - and radio shows as well - to be included into the edutainment category must additionally implement so-called "E-E strategy". If so, edutainment is, first and foremost, "the process of purposely designing and implementing a media message to both entertain and educate, in order to increase audience members' knowledge about educational issue, create favourable attitudes, shift social norms, and change overt behaviour" (Singhal \& Rogers, 2004, p. 5). As a result, it is a communication strategy that causes behavioural as well as social change that may occur at three levels since edutainment programmes have an influence on individuals, community and society. 
Without doubt, attempts to make pro-social learning more enjoyable have had a long and vivid tradition. The origins of edutainment approach can be found in a storytelling tradition. However, some scholars are of the opinion that this phenomenon is not as old as it may seem and in its modern incarnation it is rooted in more contemporary times. Piechota (2010a) indicates, for example, that educationentertainment synergy that supports social change has accompanied people from the very beginning of human history but once its form was totally different than it is in today's world when pop culture dominates - the one that is pleasure-oriented and "lives in media and via media" (p. 232).

In a sense, radio producers were the first ones to see the edutainment potential of electronic devices and broadcasts that were transmitted via them. A milestone to modern radio edutainment-education was the production of a special type of serial radio dramas. The programmes that in their formative years had been created mostly for their artistic value but in the late forties and early fifties of the last century started to incorporate into their body deeper message to promote favourable attitudes or behaviours and, what follows, bring about social change - also in the socio-political sphere, not only in the interpersonal one (Singhal \& Rogers, 2004). The main purpose of these radio broadcasts was - and still is - to show the audience how to live safe, healthy, and happy lives and mobilize them to prosocial activity.

Now it can be acknowledged after Singhal and Rogers (2004) that radio edutainment "is a worldwide phenomenon, with almost every nation having, or having had, an E-E project” (p. 17). At first, these programmes became very popular in Bangladesh, Indonesia, Ghana, Guinea, Haiti, Senegal, Zambia, Nepal, Tanzania, India, Santa Lucia, Kenya, South Africa, Jamaica, and Ecuador (Singhal \& Rogers, 2004). However, as early as the 1980s and 1990s, radio drama edutainment programmes were produced not only in Asia, Africa or Latin America where radio at that time remained the most popular tool of mass communication but also in developing and well-developed countries where audiovisual media started to hold the palm of precedence. In Poland, the most spectacular example of edutainment broadcast in the convention of serial radio drama was “Motel w pół drogi” [A Motel Halfway Up the Road] - a multipart programme that was transmitted on-air and online in the years 2006-2008. The pioneer production in the field of radio edutainment was, however, “The Lawsons".

It can be said that edutainment radio programmes of high artistic value, such as radio dramas, have always helped listeners to gain knowledge about reproductive health, family planning, HIV prevention, analphabetism, agriculture or economy in as easy-to-acquire way as possible. Broadcasts like these depicted role models for listeners and often led to social change, which is confirmed by scientific 
research (Polak, 2008; Singhal \& Rogers, 2004). Moreover, the thematic spectrum of these productions is being broadened all the time because radio is open to recipients and tries to be as close to their needs as possible. As a result, in today's world edutainment-education goes beyond the framework of mainstream topics to concentrate on such pressing, important or controversial matters as terrorism, race relations, adoption, disabilities, domestic violence, addiction, prophylaxis and treatment of cancer, ecology, or "generation gap", to name only a few. This process will probably intensify in the future since producers more and more often pack edutainment content into fictional broadcasts or popular scientific programmes but also into other, more complex, radio genres.

All things considered, this understanding of edutainment phenomenon corresponds with Frydryszek's (1997) views on radio and its cultural function and may be treated as a kind of buckle to this analysis. Specifically, the following quotation: “'Culture-making' in a broad sense, does not begin with or end with the presentation of artistic achievements of a high standard, offering patronage over them, stimulating their development. This is a very important field of radio activity, but it is also - besides the already discussed example of creating the system of information of the highest order - choosing from the reality that surrounds us the topics for radio discussion that are based on, for example, the values that are considered to be typical of Polish culture” (Frydryszek, 1997, p. 84).

Consequently, radio programmes that are created according to edutainment rules may be links between different nations. By and large, they are a bridge between culture and language. Naturally, they connect distant places and individuals who live there but, more than anything, they contribute to "propagation and spread of regional culture”. Undoubtedly, this idea lays behind the cooperation between Fun Kids radio and the Polish Cultural Institute in London.

\section{THE COOPERATION BETWEEN FUN KIDS RADIO AND THE POLISH CULTURAL INSTITUTE IN LONDON}

The Polish Cultural Institute in London is a part of the Polish diplomatic mission that is subordinate to the Ministry of Foreign Affairs. Its activity "is dedicated to nurturing and promoting cultural ties between the United Kingdom and Poland, both through British exposure to Poland's cultural achievements, and through exposure of Polish artists and scholars to British trends, institutions, and professional counterparts" (Polish Cultural Institute, 2017, p. 1). In short, it has been established to strengthen exchanges and expand cooperation in fields such as 
culture, education, science and social life. Accordingly, it often organizes many important film, theatre, music, literature or visual arts events independently or in association with most notable British partners that conduct cultural projects.

Fun Kids radio, on the other hand, fills important media market gap to satisfy the needs of "radio's biggest unserved audience" - child listeners. It is the only radio station in the UK that addresses mix of music, stories and competitions to children aged 14 and under and their parents, though, its core audience is 7-12. Being a multi-platform brand, Fun Kids radio communicates its message through traditional receivers as well as computers as it provides both digital and online services. On February 29, 2016, this radio station stopped broadcasting on local scale - limited to London area - and changed into a nationwide broadcaster. It became possible from the moment a new multiplex was launched. Since then all programmes can be listened to across the UK on DAB Digital Radio and on mobile devices but also online at funkidslive.com (Sherwin, 2016).

Listening figures speaks for the assumption that today Fun Kids is the most prominent radio station for children in the UK with 6,200 on-air listeners. It can boast of 32\% year on year audience growth. Its broadcasts reach 482,000 unique listeners every month. Additionally, as many as 120,000 young people listen to this station via funkidslive.com. By the same token Fun Kids radio generates 1 million pageviews. It has, moreover, 1,6 million YouTube viewers per month who can watch 12 channels with bespoke pre-teen content. This broadcaster is the biggest provider of audio materials on demand in the United Kingdom as well. On average, 100,000 listeners monthly download its audio and video content. The station's newsletter is subscribed by 30,000 people. The audience consists also of 102,000 Pop Jam followers and more than 4,530 Facebook and 4,520 Twitter fans. More importantly, interaction between Fun Kids radio presenters and their child listeners is not always media-mediated. The listener-friendly attitude of the station in the form of face-to-face contact manifests itself through live school roadshows and family festivals, including British Summer Time and On-Roundhay. This thoroughly designed broadcasting strategy is created to entertain the young and help them to learn. It allows children to use their imagination and develop interaction skills but, more importantly, it makes them more aware of the world environment (Ciepłucha, 2017).

The cultural profiles of both institutions and their concern about children made them partners a few years ago. The cooperation started when it was noticed that there was a need for radio programmes that would foster mutual understanding among the young with Polish roots that were a constant element of the British melting pot and their British classmates. Just before the official premiere of their 
first joint project, Chojnacki (Keynes, 2016) explained the motives for creating a new edutainment radio programme for this group of listeners as follows: "The series is a great first introduction to Poland, its culture and customs for the youngest explorers. After 2004 Poles have become a substantial group in a cultural landscape of the United Kingdom with an estimated over 1 million living here currently, many of them attending kindergartens and schools. The Polish Cultural Institute in London hopes that 'Where in the World? Poland!' will not only offer a guide and fun way to get to know the culture of Polish school friends but will fire curiosity and encourage the listeners to search further and experience more Poland after the series ends" (p. 1).

This wishful thinking was changed into reality when the first of 10 episodes, about 10 min. each, appeared on-air on October 1, 2012. They were broadcast daily at 6:00 p.m. as segments of "Ten Club” with Luke after-school programme as well as during weekends at 3 p.m. These features were also available in the form of live streaming and for free download on Fun Kids iTunes podcast channel.

Thanks to them young listeners could "travel" across Poland to solve riddles as well as gather information of this country and people of the nation with an adventurer John Iflyalot - the main character in the series. The content of this programme oscillated around topics such as geography, culture and history so that children explored great Polish animals ("Wildlife" episode), countryside and plant life, famous scientists and musicians, legends, storybooks, food, celebrations like Fat Thursday or Truancy Day, inventions - from X-Ray machines to Windscreen Wipers - and key hints for tourists since "Everyday Poland" episode, in a sense, was the guide for those who want to go on "audio" sightseeing tour.

Full of humour and interesting facts, "Where in the World? Poland!” quickly turned out to be a great success, similarly as the campaign that promoted the series. Within the first month of on-air existence the episodes reached over 173,000 listeners. A further 127,000 media users were engaged in on-air activity around the features. 315 people downloaded the show online in the audio form and there were 2,827 viewers to this content on funkidslive.com (Case Study..., 2013). A few months later, this audio programme was downloaded via radio website and iTunes channel more than 5,000 times. Online pages of the radio show were viewed by 6,091 child listeners and 600 parents were interested in the subject and asked for additional information about Poland (Where in the World..., 2017). The total amount of pageviews in May 2017 was at the level of 30,905. The most popular pages at that time were "Famous Scientists", "Engineers", "Inventions from Poland”, and "Quickfire Guide to Poland”. On average, the listeners spent 6.40 minutes per webpage (Ciepłucha, 2017). 
The extra edutainment factor in case of this series was additional texts and graphics that were depicted on dedicated website. The following advertisement supports the view that in 2012 sound was no longer the only resource for "Where in the World? Poland!”: “Fearless in his pursuit of knowledge, there isn’t an ocean too wide or a cave too deep or a desert too dry to keep him from the quest! So where in the world was John Iflyalot last seen? In Poland! And right here you can find out everything he's learnt so far! [...] But if you can’t wait until then, we've got good news. John has left a series of written accounts which you can read right here!” (About Where in the World?, 2017, p. 1).

What is interesting, the episodes of this programme are also the examples of edutainment in the broader sense as this audio content was a catalyst for the organization of outside radio station activities that celebrated the series. They had the form of free workshops for kids that were prepared by Akademia Pstryk foundation as well as June versus July group and were held in public libraries in London, Manchester and Edinburgh. During them, 100 participants created 3D letters to Santa Claus, tasted the traditional food and spent nice time with their parents. Fun Kids radio played an active role in the promotion of this edutainment initiative on air (Presentation of Polish..., 2012). Special advertisements were also published on the online pages of Polish Cultural Institute in London.

The second series created by the same institutional tandem - "Learn Polish" - was broadcast in two tranches. Ten radio features were released in 2014 and ten more in 2015. The aim of both was to teach listeners Polish language (Ciepłucha, 2017, pp. 6-7). Similarly, as the previous edutainment radio initiative of the Cultural Institute in London and Fun Kids radio, each of these episodes was a component of the afternoon drive time block and was transmitted every day at 6:00 p.m. Their primary task was to help children master their first language phrases and words in Polish. Following the plot about the adventures of Alex and her mum - the main characters in the story who were preparing for a visit to Poland - the young were given the whole catalogue of useful topics. The vocabulary was ordered according to a thematic key and divided into a few sections: "Meet \& Greet”, "Let’s Play", "At the Supermarket”, “Animals”, “Cooking”, “School”, “Nature”, “Travel”, “Eating out”, “Weather”, "Sports”, “Music”, “Colours”, “Numbers”, “Family”, “Body”, and "Days of the Week". Some culture-specific words were repeated in the part two of "Learn Polish" as well, other were completely new for the audience of Fun Kids radio.

To motivate children to listen to this "audio glossary" based on mini situational scenes, the authors of this series issued the following message to their addressees: "Speaking another language is one of the coolest skills to have - and 
as Polish is the second most spoken language in the UK, it's great to know a bit of it! To help you out we've created this brand new kid's guide to help you learn Polish! [...] So whether you want to say good morning - dzień dobry - or ask for a tasty pastry - drożdżówka - you'll be able to learn it and hear exactly how it's pronounced” (Learn Polish..., 2017, pp. 1-2).

Still, the promotion of these edutainment materials was through online banners, newsletters and Facebook posts. Methods of distribution of "Learn Polish" part I were the same as in the case of "Where in the World? Poland!". This education-entertainment content was available to listen again via funkidslive.com, Fun Kid's YouTube and iTunes channels. However, the appearance of part II of this series was accompanied by 20 videos illustrating the radio lessons of Polish language (Ciepłucha, 2017, pp. 6-7). Godlewska (Learn Polish..., 2017) commented on the adding of these visual aspects that can be seen as additional edutainment benefits: "We were positively surprised about the popularity of the first season of "Learn Polish!” and decided to build up on this success with more episodes as well as colourful videos that will add a visual aspect to the learning experience. We are delighted to be working with Polish illustrator Tomasz Samojlik, who created a series of eye-catching cartoons for the 20 brand new videos. We hope that thanks to "Learn Polish!" audio and video episodes more and more children will be eager to learn our beautiful and not that difficult language as well as explore further the riches of Polish culture after the series ends” (p. 1).

All in all, listeners found this more advanced way of radio visualisation very attractive. Additional textual content on dedicated pages within "Learn" section of the Fun Kids website was more willingly consumed than before. 113,933 listeners visited www.funkidslive.com till May 22, 2017, who usually spent 9.50 minutes on each page. Most often they chose audio episodes entitled "Meet and Greet", "Family", "Body", and "Animals". Thematic hierarchy looks slightly different when the favourite videos of the young are analysed. Besides episodes about animal kingdom and greetings, radio users liked watching "Let's Play" and "At the Supermarket" the most. The cartoons to first and second series of Polish language radio lessons were watched by 107,291 members of the child audience (Ciepłucha, 2017).

The cooperation between two institutions went so well in the past that this year "Robot's Polish Power Pack" has been broadcast. The series consists of 12 audio features for broadcast during the first week of each month. Naturally, all episodes can also be downloaded after their on-air debuts via computers (Ciepłucha, 2017). The novelty in comparison to the edutainment radio series that has been discussed above is the shift of their transmission time. This time episodes of this 
programme are embedded into the radio production flow but they also are easily distinguishable elements of Fun Kids radio breakfast show.

The plot of the series is summarized on the dedicated website as follows: "Robot from the Fun Kids Breakfast show has got himself a new pal - Korneliusz Kog from Poland! Robot's been trying to get to know him better - the trouble is... Robot doesn't know any Polish words! He’s downloaded a Polish language pack so he can talk to his robot friend" (Listen to Robot's..., 2017, p. 1-2).

Additionally, children are told that Polish letters look the same as in the British alphabet but should be pronounced in different manner. Audio material is supplemented by textual information so the young can also broaden their cultural knowledge. While reading the website, listeners may learn, for example, that letter "c" can be found in the word "Barszcz" [Borsch] - a very special soup made of beetroot that is served at Christmas, or "Makowiec", which is a sweet cake with poppy seeds inside. To show the audience the complexity of phonology, the authors of episodes give the transcription of difficult words in brackets as in the words: “córka” [TSÓR-ka], “cegła” [tsEGWa] or “praca” [PRA-tsa]. In this way, the hints on the correct pronunciation are presented to the listeners. The sound and textual content that has been broadcast so far with this kind of explanations has acquainted children with letters: “c”, “cz”, “dzi”, “ $1 ”$, “ż”, “w”, “j”, “ch”, and “sz”.

The same transcription strategy has been used for 12 animated videos that are the integral part of "Learn Polish!" audio series. Short films are based on a very popular video game - Minecraft - and can be watched online and via YouTube channel. Matt Deegan, the manager of Fun Kids radio, confirms that the station decided to visualise its content in this form when it was realised that "if your radio station targets children and needs to be in all the places your audience is, then Minecraft should be one platform on your list” (Martin, 2015, p. 1).

The story behind this production is that the presenter promised his sidekick (the robot) to help him remember the correct pronunciation of different sounds by creating virtual reality full of creatures and objects which names contained in their structures the same letters that had been introduced earlier during the radio morning show episodes. Sean Thorn, therefore, plays the role of "a tour guide" who "walks" with listeners around virtual places. A split-screen technique allows the young to see the presenter in the square space in the top left corner while his moves in the game are displayed on the rest of the screen. When the presenter meets characters, or sees objects while travelling through virtual spaces he asks Robot to pronounce their names so that children could hear them. In this way, the process of teaching takes place. Synchronically, the young can see the phonetic transcription of given words at the bottom of the computer screen. 
There is no denying that these animation films build engagement of radio listeners (107,291 video views). It is worth adding that to promote this type of edutainment content and encourage listeners to watching films, a competition for on-line and on-air listeners was carried a few months ago. For the winners, Minecraft gift cards were prepared. There were 783 entries to the content and 370 opt-ins (Ciepłucha, 2017).

\section{CONCLUSION}

Delivering his speech in Łazienki Królewskie during the visit of the Royal Family in Poland in July 2017, Prince William emphasised the importance of links between Poland and the UK that were stepped in a rich history, commercial relations and cultural exchange. He also said that such links offered much promise and opportunity for the future. Undoubtedly, radio output like three series that have been produced by the Polish Cultural Institute in London and Fun Kids radio can tighten these intercultural links and make the relationship between both countries and nations stronger. In consequence, some segments of radio "megagenres" that are full of the culture-specific knowledge about Poland - its customs, traditions and language - may become, due to their user-oriented specific, an interesting form of non-formal education that will help to raise future generations in a spirit of tolerance and mutual understanding, which is especially important in the face of Brexit.

However, the role of programmes that has been discussed in this article is more important than it may seem at first sight. Looking from a very broad perspective, these radio broadcasts may serve as a catalyst for the discussion on the so called 'mass media mission' - the idea that used to be entrusted entirely to a special responsibility of public broadcasters. They may even provoke a redefinition of this concept.

Of course, there is no clear mass media mission statement but programmes such as "Where in the World? Poland!”, “Learn Polish!”, and "Robot's Polish Power Pack" prove that not only a public media sector can provide programming to significant audiences that meets the highest standards. In the highly competitive and unstable markets commercial radio stations may also keep in with the mission of service to community. The broadcasts that result from the cooperation between Fun Kids radio and the Polish Cultural Institute, therefore, may be viewed through the prism of role models for media practitioners and scholars who do not believe that the idea of carrying out the broad ranging public media mission in the form 
of commercial radio programmes is possible. The listening figures that refer to three radio series that are presented in this article clearly demonstrate that modern broadcasts such as "Where in the World? Poland!”, “Learn Polish!”, and "Robot's Polish Power Pack" do not have to be marginalised. On the contrary, listenerfriendly, original and challenging radio programmes that inscribe themselves into the edutainment approach can ideally reach child audience, on the condition that broadcasters wisely adjust both their form and content to child's needs and the requirements of the audiovisual era. Moreover, transmissions like these may help radio to retain its status of a modern, attractive and resilient mass medium that challenges children's mind, inspires their spirit, preserves national memory as well as enhances intercultural dialogue to promote global understanding.

\section{References}

Bauer, Z. (2009). Dziennikarstwo wobec nowych mediów. Historia, teoria, praktyka. Kraków: Universitas.

Bełkot, A. (2007). Nowe formy gier i zabaw: edutainment, infotainment, docutainment. In: A. Sudryk, \& J.Z. Szeja (Eds.), Kulturotwórcza funkcja gier: gra jako medium, tekst, rytuał (pp. 29-42). Warszawa: Wydawnictwo Naukowe UAM.

Ciepłucha, A. (2017). The report about a Fun Kids campaign sent by Agnieszka Ciepłucha, the head of PR and marketing at Fun Kids radio, to the author of this article in private correspondence dated May 22, 2017.

Drzewiecki, P. (2010). Renesans słowa. Wychowanie do logosfery w kulturze audiowizualnej. Toruń: Wydawnictwo Adam Marszałek.

Dumitrescu, V.M. (2013). Culture as Communication: Communication Style across and within Cultures. Synergy, 1, pp. 84-91.

Dziadzia, B. (2002). Media jako kultura wobec i ku wspólnocie. Kultura i Edukacja, 3-4, pp. 161-169.

Fras, J. (2012). Podstawy identyfikacji i typologii wypowiedzi w mediach masowych. In: E. Kulczycki, \& M. Wendland (Eds.), Komunikologia. Teoria i praktyka komunikacji. Vol. 3 (pp. 13-29). Poznań: Wydawnictwo Naukowe IF UAM.

Frydryszek, P. (1997). Uwagi i niepokoje radiowego praktyka. In: T. Lesiak (Ed.), Radio. Szanse i wyzwania. Materiały konferencji "Kulturotwórcza rola radia" (pp. 79-85). Kraków: Międzynarodowe Centrum Kultury i Polskie Radio Kraków S.A.

Gajda, J. (2000). Kulturotwórcze i edukacyjne funkcje mass mediów. In: W Strykowski (Ed.), Media a edukacja: III Międzynarodowa Konferencja (pp. 157-167). Poznań: eMPi 2.

Giri, V.N. (2006). Culture and Communication Style. Review of Communication, 6(1-2), pp. 124-130. DOI: 10.1080/15358590600763391.

Golka, M. (2008). Bariery w komunikowaniu i społeczeństwo (dez)informacyjne. Warszawa: Wydawnictwo Naukowe PWN.

Hajduk-Nijakowska, J. (2012). Kulturowy kontekst komunikowania. In: E. Kulczycki, \& M. Wendland (Eds.), Komunikologia. Teoria i praktyka komunikacji. Vol. 3 (pp. 149-160). Poznań: Wydawnictwo Naukowe IF UAM. 
Hall, E. (1985). The Silent Language. New York: Doubleday.

Hopfinger, M. (1985). Kultura współczesna - audiowizualność. Warszawa: Państwowy Instytut Wydawniczy.

Iwanicka, A. (2010). Edutainment - sposób na edukację w dobie kultury popularnej. In: D. Hejwosz, \& W. Jakubowski (Eds.), Kultura popularna - tożsamość - edukacja (pp. 231-239). Kraków: Oficyna Wydawnicza “Impuls”.

McLuhan, M. (1964). Understanding Media. The Extensions of Man. London \& New York: Signet Books.

Moemeka, A. (1989). Communication and African Culture: A Sociological Analysis. In: S.T. Kwame Boafo (Ed.), Communication and Culture: African Perspectives (pp. 1-10). African Region: Africa Church Information Service.

Piechota, M. (2009). Pułapki edutainment (na przykładzie programu Clever! Widzisz i wiesz). In: M. Filiciak, \& G. Ptaszek (Eds.), Komunikowanie (się) w mediach elektronicznych. Język, edukacja, semiotyka (pp. 204-222). Warszawa: WAiP.

Piechota, M. (2010a). Edurozrywka - przyczynek do opisu zjawiska. In: M. Graszewicz, \& J. Jastrzębski (Eds.), Teorie komunikacji i mediów. Vol. 2 (pp. 231-239). Wrocław: Oficyna Wydawnicza “Atut”.

Piechota, M. (2010b). Działania edurozrywkowe w telewizji. In: M. Graszewicz, \& J. Jastrzębski (Eds.), Teorie komunikacji i mediów. Vol. 3 (pp. 307-319). Wrocław: Oficyna Wydawnicza "Atut".

Singhal, A., \& Rogers, E.M. (1999). Entertainment-Education: A Communication Strategy for Social Change. Mahwah, New Jersey \& London: LEA.

Singhal, A., \& Rogers E.M. (2004). The Status of Entertainment-Education Worldwide. In: A. Singhal, M.J. Cody, E.M. Rogers, \& M. Sabido (Eds.), Entertainment-Education and Social Change: History, Research and Practice (pp. 3-20). Lawrence Erlbaum Associates Inc., Mahwah, New Jersey \& London: LEA.

Wielopolska-Szymura, M. (2014). Radio as an Old and a New Medium: Sustaining Cultural Identities of Listeners. In: M. Oliveira, G. Stachyra, \& G. Starkey (Eds.), Radio: The Resilient Medium. Papers from the Third Conference of the ECREA Radio Research Section (pp. 115-124). Sunderland: Centre for Research in Media and Cultural Studies University of Sunderland.

\section{Online Sources}

About Where in the World? Poland! (2017). Retrieved from: http://www.funkidslive.com/learn/ fun-kids-guide-t-poland/where-in-the-world-poland-2/ (accessed: May 20, 2017).

Case Study: Where in the World? Poland! (2013). Retrieved from: http://think.funkidslive. com/wp-content/uploads/2013/05/Fun-Kids-Commercial-Pack-where-in-World-Poland. pdf (accessed: May 30, 2013).

Keynes, M. (2016). Children's Radio Station Fun Kids Explores Poland! Retrieved from: http:// www.miltonkeynes.com.pl/poradnik/kultura/179-children-s-radio-station-fun-kidsexplores-poland (accessed: May 8, 2016).

Learn Polish. Learn How to Speak the Second Most Popular Language in the UK. Retrieved from: http://www.funkidslive.com/learn/learn-polish/learn-polish/ (accessed: December 18, 2016). 
Learn Polish with Children's Radio Station Fun Kids! Retrieved from: http://edinburgh.mfa. gov.pl/en/c/MOBILE/news/learn_polish_with_children_s_radio_station_fun_kids (accessed: December 20, 2017).

Listen to Robot's Power Pack on Fun Kids! (2017). Retrieved from: http://www.funkidslive. com/on-air/listen-robots-polish-power=pack-fun-kids/ (accessed: May 8, 2017).

Lord Pattern, Chairman, BBC Trust. Retrieved from: http://www.bbc.co.uk/mediacentre/ seeches/2011/pattern_lord (accessed: December 20, 2011).

Martin, S. (2015). Are You on the Minecraft Platform Yet? Retrieved from: http://earshotcreative.com/2015/11/are-you-on-the-minecraft-platform-yet/ (accessed: May 17, 2018).

Polak, M. (2008). Edutainment - przyjemna edukacja. Retrieved from: http://edunews.pl/badania-i-debaty/opinie/66-edutainmentt-przyjemna-edukacja?showall=\&start=1.

Polish Cultural Institute (2017). Retrieved from: http://www.polishculture.org.uk/aboutus.html (accessed: March 9, 2017).

Presentation of Polish Christmas Traditions for Kids in English (2012). Retrieved from: http:// www.msz.gov.pl/en/p/msz_en/c/MOBILE/news/presentation_of_polish_christmas_traditions_for_kids_in_english (accessed: December 19, 2012).

Sherwin, A. (2016). Fun Kids: National Radio Station for Children to Launch - with DJs from The Beano. Retrieved from: http://www.independent.co.uk/arts-entertainment/tv/ news/fun-kids-national-radio-station-for-children-to-launch-with-djs-from-the-beanoa6851466.html (accessed: July 26, 2017).

Understanding Media and Culture: An Introduction to Mass Communication (2017). Retrieved from: http://klangable.com/uploads/books/Understanding-Media-and-Cuture-An-Introduction-to-Mass-Communication-1466714375.pdf (accessed: July 20, 2017).

Where in the World? Poland! With Polish Cultural Institute (2017). Retrieved from: http:// think.funkidslive.com/2013/05/14/where-i-the-world-poland-cultural-education-institute (accessed: July 20, 2017). 